\title{
Article
}

\section{Saving Soil for Sustainable Land Use}

\author{
Carmelo M. Torre ${ }^{1}$, Pierluigi Morano ${ }^{2}$ and Francesco Tajani ${ }^{3}$
}

1 Polytechnic of Bari, Department of Civil Engineering and Architecture, Via Orabona 4; Bari (Italy); E-Mail: carmelomaria.torre@poliba.it*

2 Polytechnic of Bari, Department of Civil Engineering and Architecture, Via Orabona 4; Bari (Italy); E-Mail: pierluigi.morano@poliba.it

3 Polytechnic of Bari, Department of Civil Engineering and Architecture, Via Orabona 4; Bari (Italy); E-Mail: francesco.taiani@poliba.it

Correspondence: carmelomaria.torre@poliba.it; Tel.: +39-080-596-39-28; Fax: +39-080-596-38-23.

\begin{abstract}
Our work is regarding the analysis of land use changes, in the light of "saving soil" against the expansion due to unearned plus value of land: The loss of natural and agricultural surface in front of the expanding urban environment is a critical aspect of unsustainability of urban development, especially in the way it was carried out in the past decades. The measure of the physical transition of land use and characters from a more natural condition of land surface to a new artificial one, joint with a parallel analysis of the increase of land value due to such change is nowadays a major land-policy tool. The interplay of urban economics regulation with planning, reveals new key issues in urban governance and environmental preservation. In this paper it will be shown some experiment about the impact assessment of soil take, related with the seek of valorization of property inside the planning process. Our paper reports as well about the experimental activity carried out inside the MITO Lab of the Polytechnic of Bari, where reports about property values and environmental values have been produced, specially looking at the reality of the Apulia, a southern Italian Region, that is rich of farmlands and coastlines, often invaded by constructions with a severe loss of nature, landscape and ecosystems services.
\end{abstract}

Keywords: Sustainability, Environmental Evaluation of Land use, Soil sealing soil take, land plus value recapture, transition matrix

\section{Introduction}

Soil is an important natural resource. The Earth surface works as the most important platform, by attending various functions. The creation of artificial soil, even when the artificial soil appears as a farmland, or a green urban park, causes a loss of ecological functions.

This means that urbanization, in the whole range of its aspect, creates a deficit in the natural functions of our planet. In the nowadays such natural function of the land is identified with the Ecosystem Services that soil represents.

The Hearth surface is in the same time

a) the platform where economic activities find their evident connection with property and land transformation [1], and

b) the surface where ecosystem services are provided [2]

A sustainable development should find the right balance between property and production development, and ecological quality of our life. Due to such increasing concern about the preservation of land's natural function, in the past recent years, a set of urban policies have been tested to reduce the so-called "soil consumption", trying to find a more correct balance between the spatial dimension of land use and the human urban activities.

Actually, the first steps of this path towards the savings of environmental resource start with some research programs in the Seventies, like the UNESCO MAB-Program ("Man and Biosphere", 1971), and passes through the introduction of the "Ecological footprint", when researchers from 
Wageningen University found a way to link the loss of natural environment with a spatial measure easy to be understood, not only by scholars, but also by common and young people [3].

In the Nineties after the international Conference in Rio, and the promotion of Agenda 21, the British "Town and Country Planning Association" with "Friend of the Heart" [4], set the problem in terms of urban planning, land use and property, transport and energy, and published a well-known Report. In that occasion Breheny emphasized the competitiveness of the "Compact city", counter posed to Urban sprawl. After some year the same Breheny started reflecting on feasibility of reduction of sprawl [5].

In the nowadays we arrive to link directly the representation of the Nature dissipation at the physical soil take. In fact, imperviousness (and the artificial soil) brings with itself the meaning s and the causes of climate changes, reduction of biodiversity, corruption of landscape, and exposition to the seismic and hydrological risks.

This paper tries to analyze the linkage between the trend for urban expansion and the economic driving forces that make the phenomenon of soil take a not easily reducible.

The soil take collects all the aspect that were depicted in the pioneer period of land and biology studies: a measure of surface that describes the ecosystem services [6] [7], such as ecological footprint, and a way of avoiding the dissipation of nature and soil [8], by using a compact model of urban development.

We consider that a first main step will be the attempt to produce a classification of different form of land take, according to their linkage with urban economy and property management. This is the focus of our discussion paper.

The main area of studies is the Apulia Region in the southern part of Italy. As regard the diversification of soil occupation by the built environment, we illustrate the main aspects, taking as example some emblematic cases.

At the end, we will produce a general reasoning about some spatial-economic indicators related with the real estate property change.

To give a better explanation of the never-ending pressures to expand a new built environment, despite to regenerate the old one, or just to re-use in a better way we associate the property benefit with the contrast to unsustainable urban expansion.

We will take as example the spatial dynamics of settlements in our Italian Region, that is Apulia.

\section{General aspects of land take}

In this section, we introduce the most relevant phenomena that characterize the soil take in Italy

\subsection{The loss of farmlands}

The farmland, jointly with the natural surface is the main victim of urban expansion [9]. The table n.1, reporting the available rural surface pro capita in some western countries at the end of the 90's, puts on evidence how the Italian condition of land-use was already critical [10].

If compared with France (that is do say a main competitor of the Italian Agro-industry), the rural surface pro capita was in percentage, more or less the $70 \%$ than our neighbor French nation.

The quantity of farm land is important not only in terms of loss of the landscape value (that countryside still preserves in Italy), or in terms of the "filter-function" of farms considered as buffer zones between urban and natural environments [11].[12].

The trend in the last twenty year put on evidence, not only the increase of urbanized land, despite the rural one, but also a progressive reduction of food production.

In some way farmlands represent, in their economic dimension, the guarantee of food supply for the nation.

The amount of 0.4 hectares pro capita, did not guarantee the self-sustainability of food supply for the Italian population, that is interested (as Figure 1 shows) by a declining trend. 
Table 1. Ha/pro capita of Farmlands by Country in 1996

\begin{tabular}{cc}
\hline Country & $\begin{array}{c}\text { Ha/pro capita of } \\
\text { Farmlands }\end{array}$ \\
\hline United States & 1.61 \\
Canada & 2.14 \\
U.K. & 0.31 \\
Netherlands & 0.14 \\
France & 0.57 \\
Italy & 0.40 \\
\hline
\end{tabular}

According to the Italian Ministry of Agriculture, the ratio between percentage of national agricultural production and the interior food demand is about $4 / 5$. We lost around the $20 \%$ of selfproviding of food due to the farmland reduction.

Even if the Italian agri-food market, and other derivate products from farmland (e.g. agricultural production for clothing, medicaments) are affected by positive trends, in term of pricing and rent, the progressive disappearing of the countryside produces immaterial (loss of landscape) and material damage (loss of ecosystem services). Even if biological agriculture increases, agricultural lands in general disappear.

This is a first example of trade off considerable as "wicked problems". In this trend two main factors are of interest in this paper: the urban sprawl inside the countryside and the urban expansion invading the rural ring around the city.

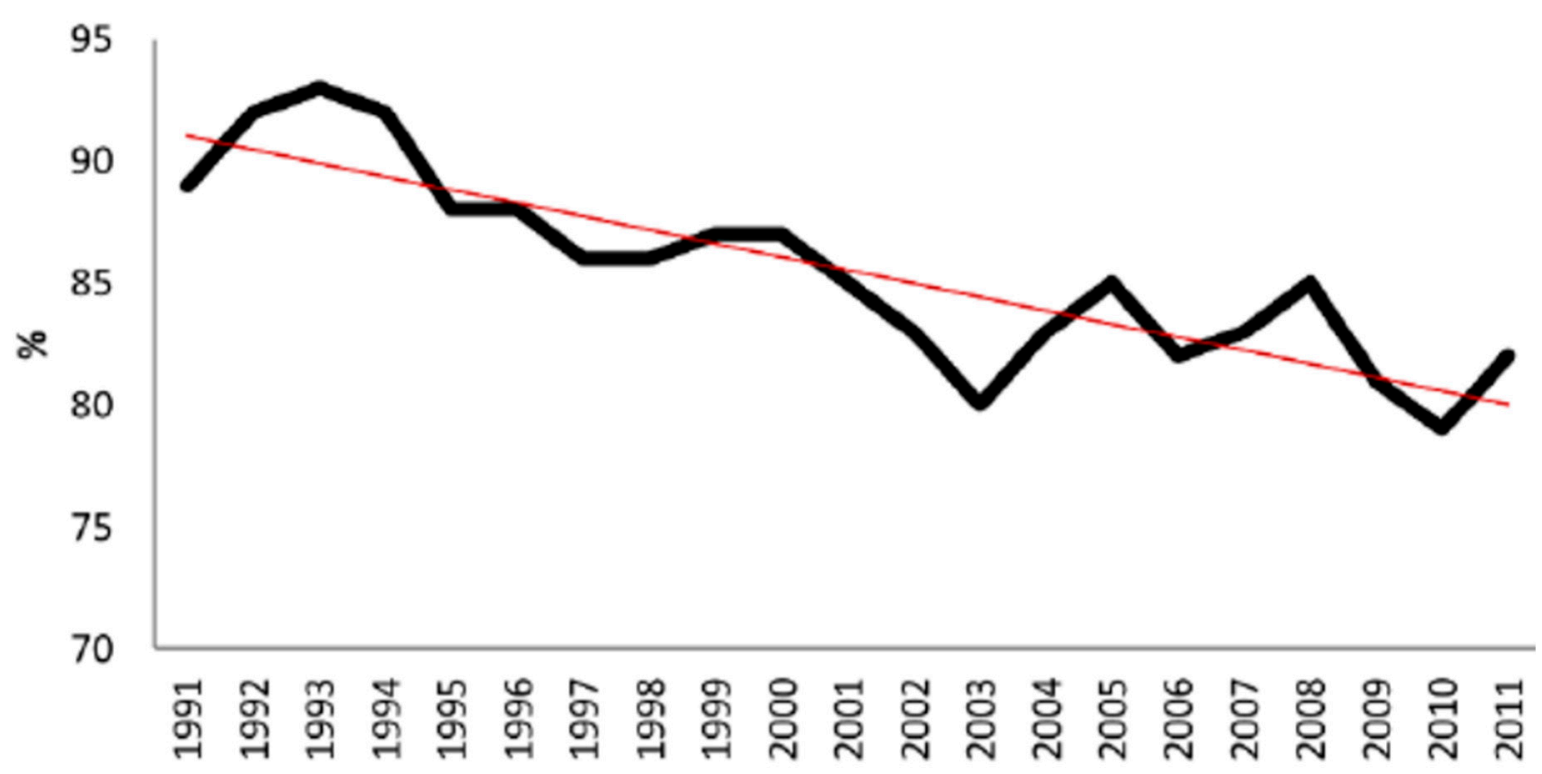

Figure 1. Percentage of food self-providing in Italy due to farmland (source: Italian Ministry of Agriculture and National Institute of Statistics)

\subsection{The coastal invasion}

Arcidiacono et al. [13] remind that a recent report on land use in Italy (dated 2015) produced by the Italian Higher Institute for environmental Research (ISPRA) underlines the coastal waterproofness due to seasonal touristic settlements as one of the most impactful phenomena on the loss of environmental and surface resources, due to the continuous urbanization and massive occupation of the Italian coastline by settlements and infrastructure.

Such phenomenon, more than for the obviously increase of imperviousness, increase the coastal vulnerability accompanied by hydrogeological instability and erosion in estuaries, causing the depletion of remarkable landscape heritage and ecosystems services. 
The study of ISPRA [14] reports that ratio waterproofing covers more less the fifth part of the soil between the soil included in the distance of 300 meters from the coast and more less the seventieth part of the land surface between 300 and 1,000 meters from the coastal line.

\section{Instruments and approaches for analyzing land take in Apulia Region}

\subsection{Lab Activities and surveys}

In this part of the paper we reason about some emblematic cases of unsustainability of soil take and their relationship with the interaction between property management and urban planning.

Most of the data that we utilize are elaborated inside the MITO Lab (Laboratory for Multimedia Information for Territorial Objects) of the Department of Civil Engineering and Architecture at the Polytechnic of Bari.

In special matter, we withdraw data elaborations from the joint work of two Observatories: the "Observatory for Real Estate and Project Appraisal", and the "Observatory for Soil saving". The data and the indicators managed inside the "Observatory for Soil saving" surveys different aspects of the "Land Consumption" or "Soil Take" with the aim to find the causes and to reflect about the tools for reducing the phenomenon

If we consider the different reports and studies on the matter, it is emerging that the concept and the measure of soil take cannot be defined uniquely. The Anglo-Saxon meaning, for example, consider the "Land Take" as the utilization of the surface for specific human activities[16] [17].

When using the term "land consumption" is always necessary to specify what kind of changes refer, moving always in the context of changes that determine the irreversible loss of all or some of the ecological functions of soils.

In this case, we have chosen to use as the main indicators those that describe the expansion of artificial surfaces in Puglia, while being aware that, depending on the criteria adopted, this might be considered excessive when permeable areas are included, or reductive, when other phenomena that do not depend from urban development but also from rural activities or excavations (like erosion, or stone breakings or desertification) are undervalued.

The most frequently used classification (e.g. Corine Land Cover) subdivide in macro-categories the artificial surface:

1. Artificial surfaces

2. Agricultural areas,

3. Natural environments

4. Wetlands

5. Water bodies.

In the Apulia Region, the institutional Geographic Information System that manage and upgrade the Regional Maps subdivides artificial soil at the second level in

1.1. residential urban areas

1.2. industrial, trade and infrastructure

1.3. mining areas, construction sites, landfills and artifacts and derelict land

1.4. artificial green non-agricultural areas

About other coverage, relevant are:

2.1. arable

2.2. permanent crops

2.3. permanent meadows (grassland)

2.4. heterogeneous agricultural areas

3.1. wooded areas

3.2. areas with shrubs and / or herbaceous

3.3. open areas with sparse or no vegetation

4.1. inland wetlands

4.2. maritime wetlands

5.1. continental waters 


\section{2. maritime waters}

\section{9. others}

It is fast understanding that in most cases the impermeable built surfaces (dwellings, sheds, schools or hospitals etc.) or just covered surfaces (road network, parking areas, etc.), are alternate with (gardens, fallow residual spaces, etc.) and empty areas that they have retained all or part of the ecological functions of agricultural and natural soils

Inside the variety of impervious surfaces only those portions of artificial surfaces which are covered with waterproof materials, as well as those areas which, although being within not "artificial" areas (for example, of agricultural areas) are equally covered of waterproof material (manufactured rural, etc.) are then included.

Most of the dynamics that generates new land consumption are strictly connected with the real estate market, and the plus value due to land use regulation that increase the land value by zoning new urban expansion.

We analyzed on a first time the undue land plus value, deriving from not justified - even if legal -planning of urban expansion.

In a second time, we emphasize the peculiarity of each case of study and finally we propose some solution.

\subsection{The use of transition matrix}

To analyze the change of land use we utilize the "Transitions Matrix" [18]. Let's explain what is the benefit of using the matrix of transitions. We can understand the advantage by recalling that, in order to calculate the consumption of soil may be used, of fact, to two basic methods:

1. The "differential" approach: with this method, when Land Cover referring to two different time lines are known, it is possible to calculate the absolute variation for each typology of surface between the known time lines.

The method requires a not-georeferenced numerical database (surfaces for each use / land cover) and is easy to apply as it is necessary to make differences between what you read at time 1 and time 2.

A possible disadvantage is that losses and gains could be quantitatively balanced each-others. For example, if during a decade we record a variation in the loss of -100 ha of agricultural cover, it may be the product of a more substantial loss, -300 hectares, which is balanced in part by a growth of +200 hectares due to further transformations. Such steps are not seen from the approach. We lose, therefore, the quali-quantitative dimension of the analysis.

2. The "flow analysis" by which instead is solved the lability of the "differential approach", isolating all transitions. The method requires a geographical database (the GIS of soil covers).

In order to use the method, we must use the "Matrix of transitions" with which the single streams by a cover $i$ to $a j$ are distinctly countable from those from $j$ to $i$ or $k$ to $j$.

By doing so, it is possible to account the real losses, before of balancing each change in the system. Among other things, it is also possible to read loss and gains of cover due to a relocation of the original covers. For example, the growth of forests in a region may be the result of a loss of wooded area in the lowlands and an increase in highlands (with all different ecological and economic implications).

In this case the transition matrix enables to detect any decrease in separate and distinct way by increments.

\subsection{The multiplier of land value}

The Multiplier of land plus value (MPV), due to the change of formal land use value, is one of the main key to analyze the causes of the seek for new soil.

Actually, the change of land-use from agrarian to urban represents, the main component of plusvalue due to an expansive planning process.

This well-known phenomenon has been, consequently, analyzed [19] [20]. 
In such occasion of land-use change, the revenue-cost ratio registers a strong betterment, due to the difference between the land-value when the promoter buys, at the sale-price of an agrarian soil, a future possible buildable area and the land-value when the promoter sales the same area just after it as been built, since the ratio between the agrarian and buildable soil varies (e.g.) between 1 up to 20 and 1 up to 100 .

Several traditional planning procedures can support the plus-value creation. Most are imputable to the weakness of local administration in managing sustainable scenarios in front of the pressures of entrepreneurs and land promoters.

\subsection{Testing the feasibility of Land Value Recapture for soil saving}

The land value recapture may become a way to rescue social benefits from the multiplication of property value due to a land-use change inside the planning process: the soil take, in the light of "weak sustainability" can be compensated by generating social grants [21].

Healey [22] suggests a set of actions:

1. recovery of direct public costs by public services generated in a given project,

2. satisfaction of need for public services, infrastructure, housing or ecological services that are not met by the market or by existing funding sources,

3. internalization of negative externalities like pollution,

4. funding mitigation of impacts on the natural environment or on landscape and cultural heritage,

5. compensation of perceived social injustices such as social exclusion or higher housing prices.

To give an answer to the imperfect compensation by land value recapture, Alterman [23] evokes "Alternative Rationales" for "indirect value recapture"

The generator of plus value supports (indirectly and directly) the value capture when the increase in land values is due to the decisions making of land use planners.

It is obvious that the satisfaction of need for ecological services and the mitigation of impacts on the natural environment could be useful to recover by land reclamation a new natural surface. But the process seems complex, as it will be shown in the further points of this paper.

As we introduced, we will provide in the next pages a repertory of examples of wicked problems related with the struggle for reducing soil take in front of high multiplier of land value.

\section{Cases of study}

\subsection{Social Housing and Public Plans for Industries}

Since the beginning of seventies, the Italian Government produced a set of new legislative instruments, to ensure the increase of the offer of soil for social housing and new industrial activities.

The main axis of this new legislative system was the "Law for Housing" n. 865 of 1971.

This law gave the possibility of expropriating soils for new urban settlements, both residential and industrial. It was a period of migration towards northern cities and, generally, from small towns to bigger metropolitan areas. The exploitation of manufacturing activities was the basis of the mainframe of new town planning policies, and workers' neighbors were created.

The Planning system introduced two new instrument: the "Extraordinary plans for popular and economic housing (PEEP)" and the "Extraordinary plans for productive settlements (PIP)".

In the nowadays the low 865 of 1971 is still applied, even it appears clear that the demand of manufacturing is decreasing, in front of the increase of new technologies and new economic sectors, and even if we face more-or-less, with a stability of the demographic trend.

One of the most peculiar aspect of these instrument is the character of urgency, that generates two main consequences:

1) when there is "no possibility of different localization" it is possible to find the land for productive settlements and social housing also in areas with special constrain landscape 
2) when public property is not available, the Municipalities can expropriate private land with a faster simplified procedure, that provides also a fast change in land use destination.

The main advantage is that it was - and still it is - possible to expropriate rural land (with a small property value) that become industrial or residential. Mostly of the times the owners of the land have been the same that were seeking for new settlements.

Therefore, the land was restituted mostly to the same owners that see their land increasing the value (approximatively) from 1 to 10 or up to 20 .

Still nowadays even if the soil take is decelerating, the few increase of land consumption are due to the application of this procedure.

The figure 2 shows the analyses produced by MITO Lab team. The white cover in the second quadrant of figure 2 represents the artificial soil at 2006 in a piece of the territory of Bari, the Capital of Apulia.

The area, at the beginning reserved by the General Land-use Plan to facilities (land value more close to the rural one) becomes residential (land value 20 times higher than rural).

The construction starts in 2006 (year of the first release of the Regional Map) and has a follow up until 2011 (year of the second release of the Regional Map) that is readable.

In the middle of the settlements the new residential area represents the main example of soil take in the city of Bari. The second image of figure $2 b$ shows the extension of artificial lands after 2011 (red cover)

The second case (Figure 3) regards a main industrial area near the coast. The comparison between 2006 and 2011 shows the increase of the shed covered land. This area is located on a hydrological basin and was interested by serious episodes of flooding.
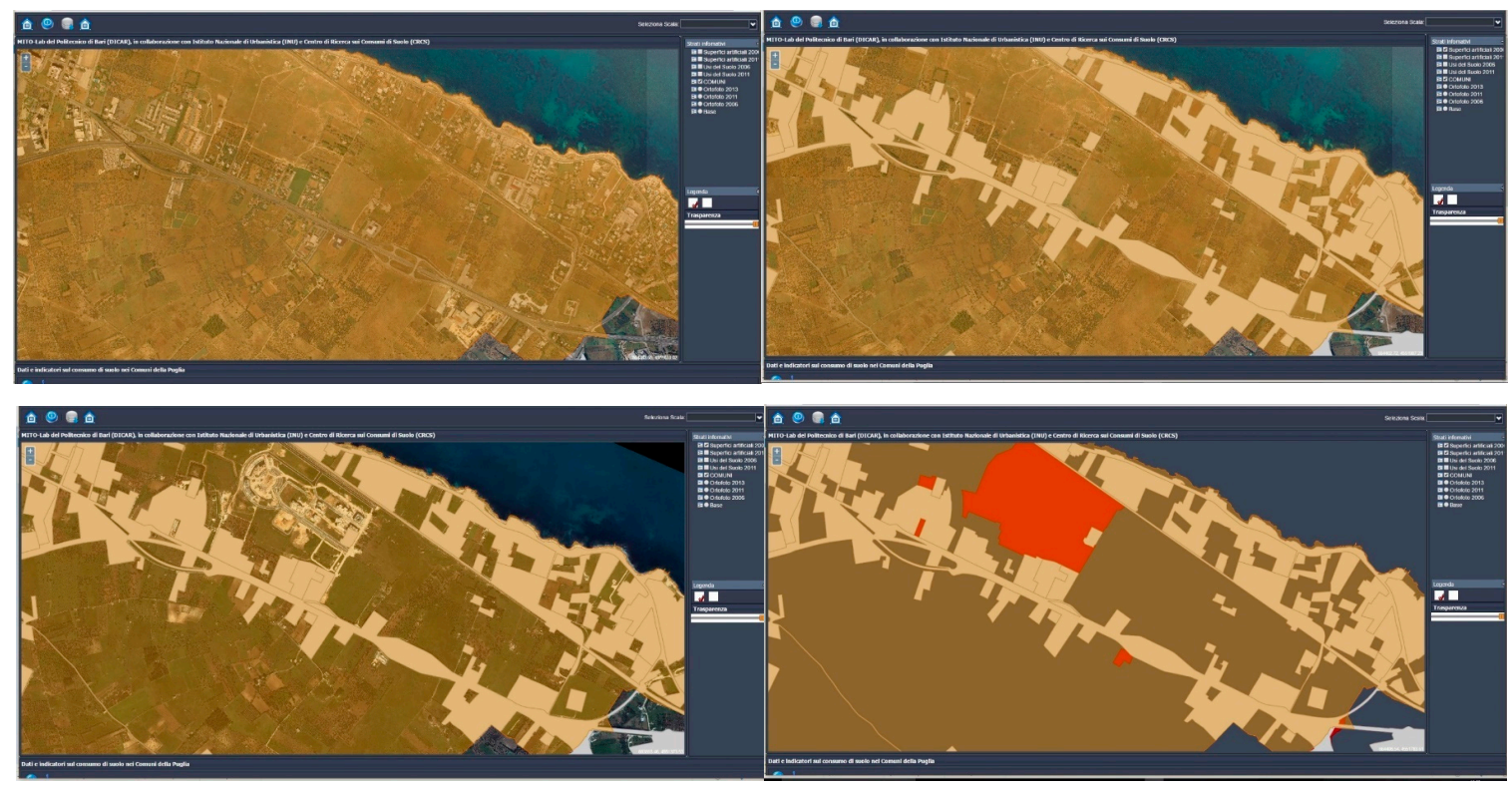

Figure 2. The Birth of a new Residential Area using law 865/1971 in Bari 

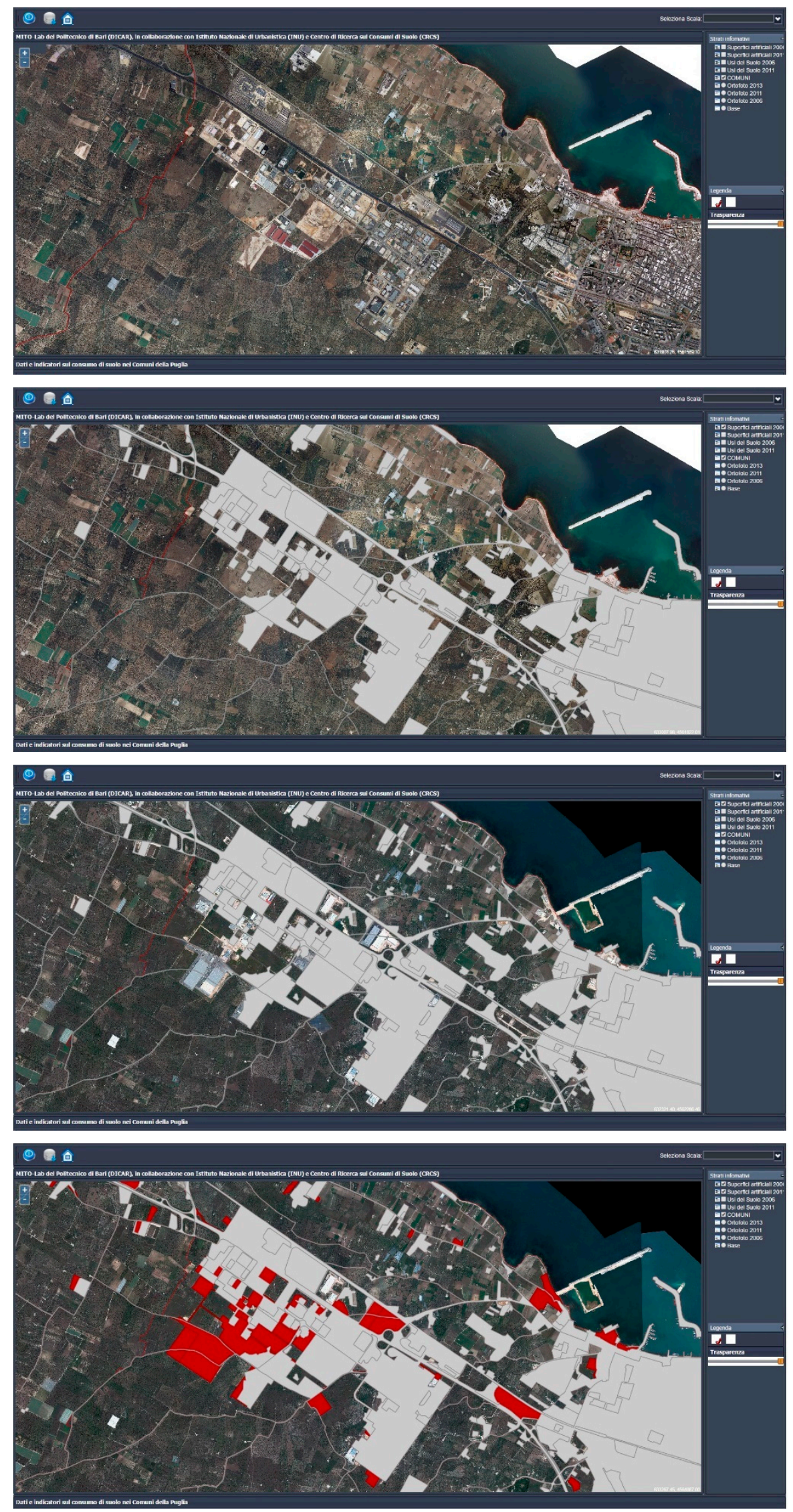

Figure 3. The growth of a new Industrial Area 


\subsection{Salento Built Coast}

Apulia, since it owns the most relevant coast in Italy, in ratio of its surface, sees a quite relevant coastal invasion. The economy of sea fruition in Apulia has been characterized since the end of seventies, and the model of the single-family seasonal household was spread all-over the Apulian coast. It corresponds to the easiest way to build - with small-technological characters, and costs touristic lodgments. Along its nearly $800 \mathrm{~km}$, Apulia is the region with the greater extension of the coastline in Italy. The $65 \%$ of the coast is identified by the Regional Landscape Plan as a main part of the Core Areas for the Ecological Network for Biodiversity, and, therefore, as subject of primary protection. Despite this, in Apulia, there is a wide land use linked to the growth of coastal settlements, due to tourism and in most of cases, the coastal housing is seasonally used. This phenomenon has been a growing trend over the last decades due to the increase of the tourist flow from abroad and from other Italian regions.

In the Apulia region, Salento is one of the most emblematic examples. According to ISTAT in the 2014 more or less four million of tourist signed their daily presence in Salento. The Salento coast, represents the tourist area of major interest with predominantly receptive systems composed of hotels, residences, guest houses and B \& B. Salento (according to data by ISPRA 2015) is the location where we discover some of the highest proportions of land consumption due, mainly, to a deregulated housing. A main case of study is the area of Porto Cesareo. The territory of the Municipality of Porto Cesareo is running along a strip of land on the Ionic Sea (Fig 4). The town has the $83 \%$ of residential stock devoted to seasonal use. In the period between 2006 and 2011 the transition matrix shows a very small increase in artificial soil (Fig 5).

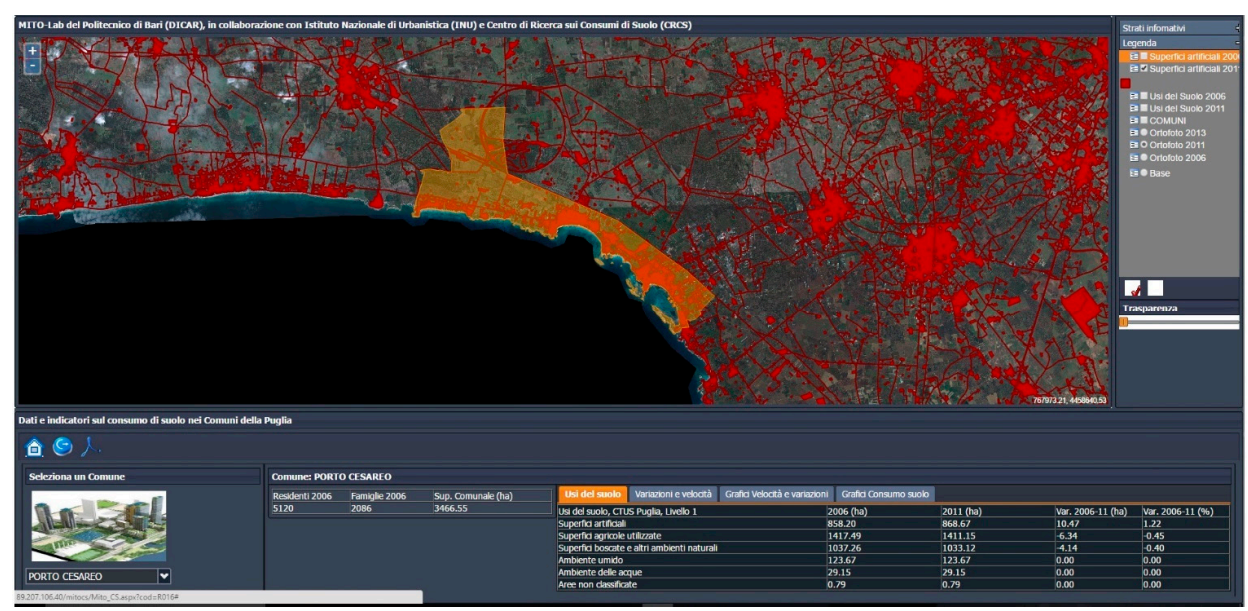

Figure 4. The Area of Porto Cesareo Municipality

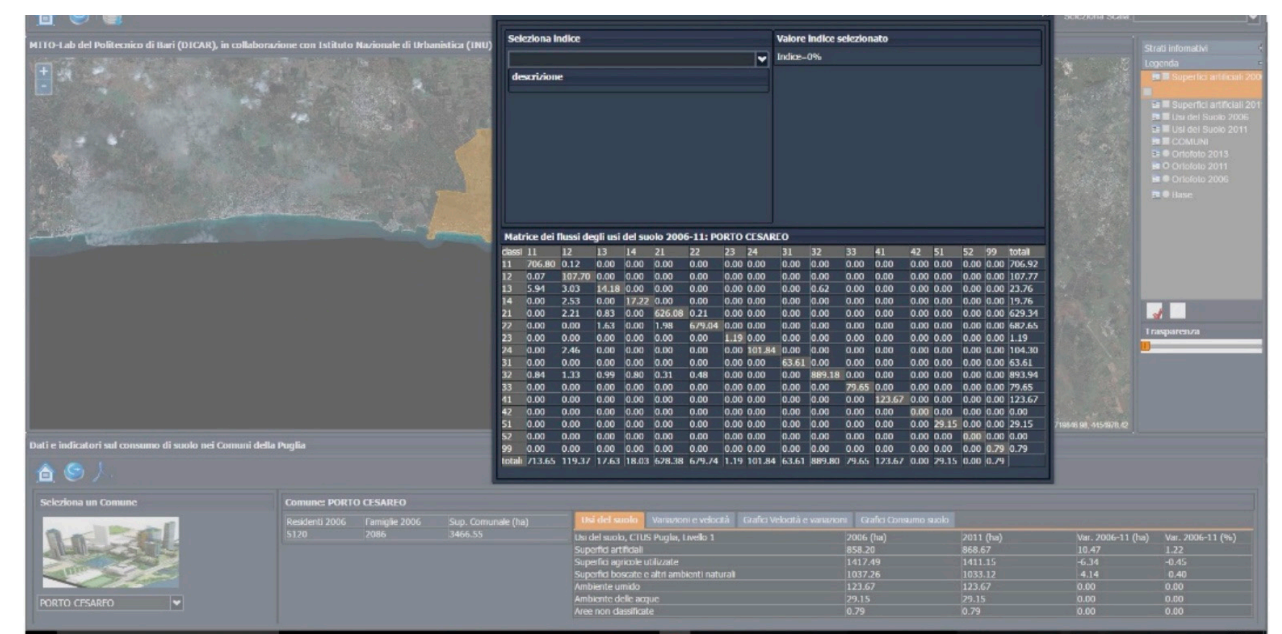

Figure 5. The Transition Matrix from Mitocs (Geo-database of soil take of MITO Lab) 
When we observe the matrix of transition in the first two rows we find the change of all categories to residential artificial surface.

In the same way in the second row we find the change of all categories to industrial artificial surface, in the third to various artificial, in the fourth in artificial green.

The transition of values is represented in the second couple of rows, where the multiplier calculates the increase of value with this formula:

Where

$V_{\text {T2 }}$ is the total value at the time 2

Vut1 is the unit value at the time 1

n is the multiplier of land value from the use at time 1 to the use at time 2

$\Delta \mathrm{S}_{\mathrm{Ha}} \quad$ is the added surface to the artificial category of land use

Table 2. The Transition Matrix for Porto Cesareo as extracted from MITO CS Monitor (Consumption of Soil Monitor)

\begin{tabular}{|c|c|c|c|c|}
\hline Categories & 11 & 12 & 13 & 14 \\
\hline 1.1. residential urban areas & 706,80 & 0,12 & 0,00 & 0,00 \\
\hline 1.2. industrial, trade and infrastructure & 0,07 & 107,70 & 0,00 & 0,00 \\
\hline 1.3. mining areas, construction sites, landfills and artifacts and derelict land & 5,94 & 3,03 & 14,18 & 0,00 \\
\hline 1.4. artificial green non-agricultural areas & 0,00 & 2,53 & 0,00 & 17,22 \\
\hline 2.1. arable & 0,00 & 2,21 & 0,83 & 0,00 \\
\hline 2.2. permanent crops & 0,00 & 0,00 & 1,63 & 0,00 \\
\hline 2.3. permanent meadows (grassland) & 0,00 & 0,00 & 0,00 & 0,00 \\
\hline 2.4. heterogeneous agricultural areas & 0,00 & 2,46 & 0,00 & 0,00 \\
\hline 3.1. wooded areas & 0,00 & 0,00 & 0,00 & 0,00 \\
\hline 3.2. areas with shrubs and / or herbaceous & 0,84 & 1,33 & 0,99 & 0,80 \\
\hline 3.3. open areas with sparse or no vegetation & 0,00 & 0,00 & 0,00 & 0,00 \\
\hline 4.1. inland wetlands & 0,00 & 0,00 & 0,00 & 0,00 \\
\hline 4.2. maritime wetlands & 0,00 & 0,00 & 0,00 & 0,00 \\
\hline 5.1. continental waters & 0,00 & 0,00 & 0,00 & 0,00 \\
\hline 5.2. maritime waters & 0,00 & 0,00 & 0,00 & 0,00 \\
\hline 9.9. other uses & 0,00 & 0,00 & 0,00 & 0,00 \\
\hline Total artificial uses & 713.65 & 119.37 & 17.63 & 18.03 \\
\hline
\end{tabular}

The transition matrix allows to analyze the cost effectiveness of the transition. In fact, we have a negative balance in the transition, due to the bigger loss of value of productive and commercial areas $(-366,40 \times 10.000$ euros) respect the smaller increase of land use for residential activity $(50,60 \times 10.000$ euros).

This shows as in the overcrowded coastal areas the transition created unbalance environmental impacts. The negative trend, pushed the farmland use towards the coverage by thermal solar and photovoltaic panels.

The phenomenon is not visible in the Municipality of Port Cesareo, due to the absence of free farmland.

It was starting between 2006 and 2011 in the background of the coastal settlements Porto Cesareo, belonging to the Municipality of Nardò. 
If we observe figure 6, we can notice that most of the photovoltaic coverage is not colored in white (artificial land until 2006) and in the same tome it is not colored in red (artificial land until 2011).

Table 3. The estimate of variation of land value

\begin{tabular}{ccccc}
\hline Typology of transition & residential & industrial & $\begin{array}{c}\text { mining } \\
\text { landfills } \\
\text { derelict etc. }\end{array}$ & $\begin{array}{c}\text { non-rural } \\
\text { artificial } \\
\text { green }\end{array}$ \\
\hline $\begin{array}{c}\text { From urban to urban artificial soil } \\
\text { From non-artificial to urban artificial soil }\end{array}$ & 6,73 & 11,68 & 3,45 & 0,80 \\
$\begin{array}{c}\text { land value VuT2 variation from urban to } \\
\text { urban artificial land use (unit=10 } \\
\text { thousands of euros) }\end{array}$ & 134,60 & 6,00 & 3,45 & 0,80 \\
$\begin{array}{c}\text { land value VuT2 variation from non- } \\
\text { artificial to urban artificial land use } \\
\text { (unit=10 thousands of euros) }\end{array}$ & 84,00 & 600,00 & 69,00 & 0,80 \\
\hline
\end{tabular}

Photovoltaic therefore represent a further way to increase the land value multiplier. The destiny of photovoltaic is anyway related with public co-funding or de-taxation that are near to disappear. Anyway, what is going on in the area of Porto Cesareo and Nardò, put on evidence the frequent try to convert farmland also nearby the coastal settlements to obtain a new form of plus value.

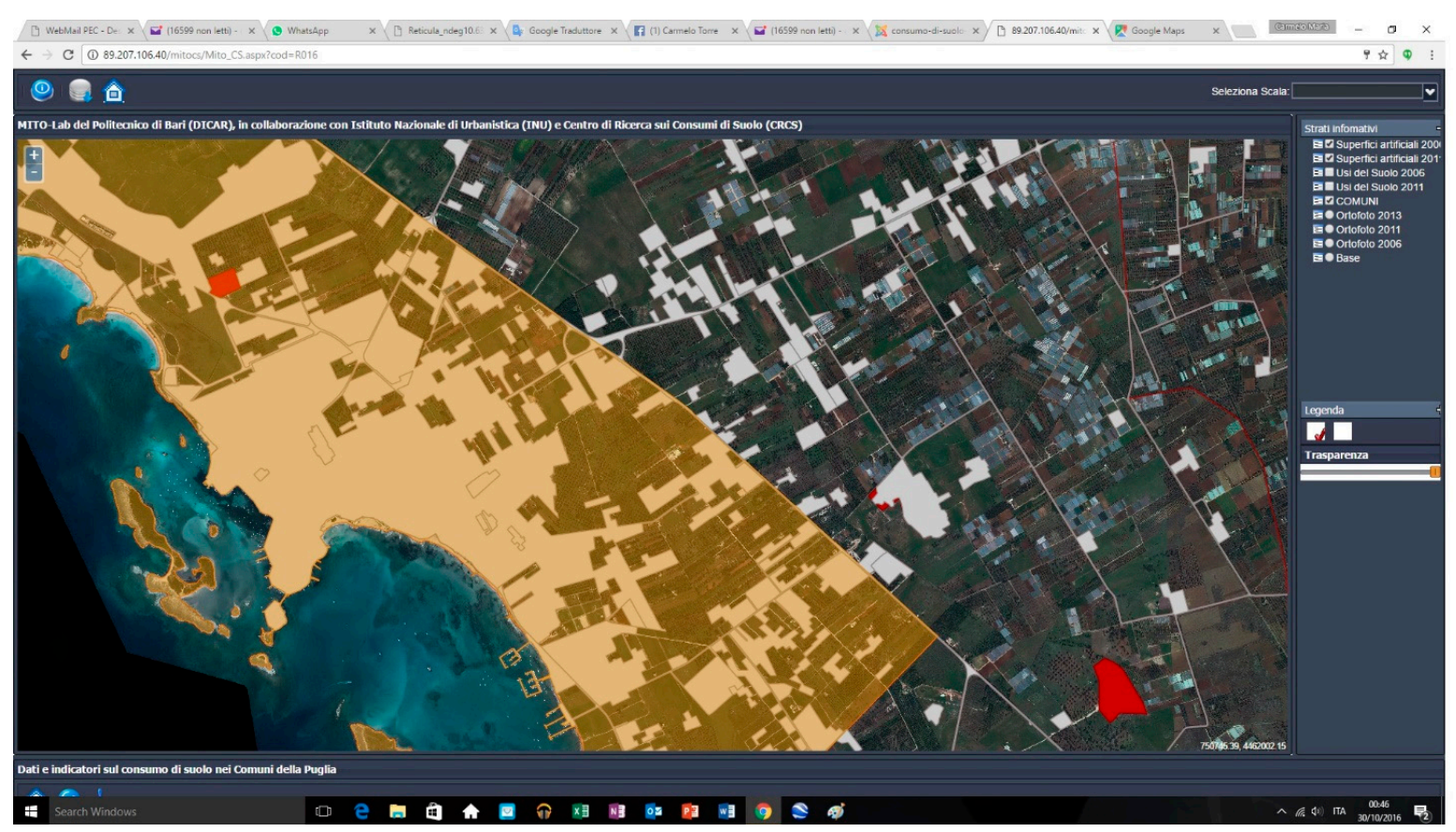

Figure 6. The use of farmland as platform for photovoltaic coverage in Nardò

\subsection{Itrian Valley and urban sprawl}

The Itrian Valley is one of the most important example of rural landscape with a strong identity, due to the peculiar countryside character. The rural landscape is interested by the appearance of the typical constructions named "Trulli". Posed in the middle of the Apulian region, among the County of Taranto, Bari and Brindisi finds its greater urban center in Martina Franca. 
More than in other Municipalities of Itrian Valley the countryside of Martina is suffering because of urban sprawl, that is due to the wish of its own inhabitants to spend the summer in the rural environments.

The peculiarity of the autochthonous occupation of rural spaces is proved by two aspects:

1) the absence of peak of use during the summer (as indicator of an increase of presences from the exterior territory)

2) the presence of a "ring" surrounding the city that has the characters of a "green urbanized belt"

In order to comprise the first aspect we consider the variation of environmental pressure during the year, utilysing a dummy variable based on of the variation of waste production and of the cost of waste disposal in Martina Franca during the year.

The increase of waste production in summer is typical of those holyday centers, where the touristic presence in some cases multiplies so evidently the waste production and disposal (see the comparison between the seasonal Porto Cesareo and the domestic-seasonal Martina Franca in fig. 7).

This variation is therefore evidenced by an index of cost, derived from the use of the Land Use Intensity Seasonality (derived from Bonifazi et al [24]), measuring the seasonal variation in artificial land use intensity (under a summer peak assumption), by using monthly waste production as a proxy of the cost of waste disposal, according with the formula:

$$
100 \times(\text { AWP-MWP)/MWP }
$$

Where

AWP $=$ waste disposal cost in August of a given year (e.g. 2015)

$\mathrm{MWP}=$ monthly waste disposal cost (in a given year)

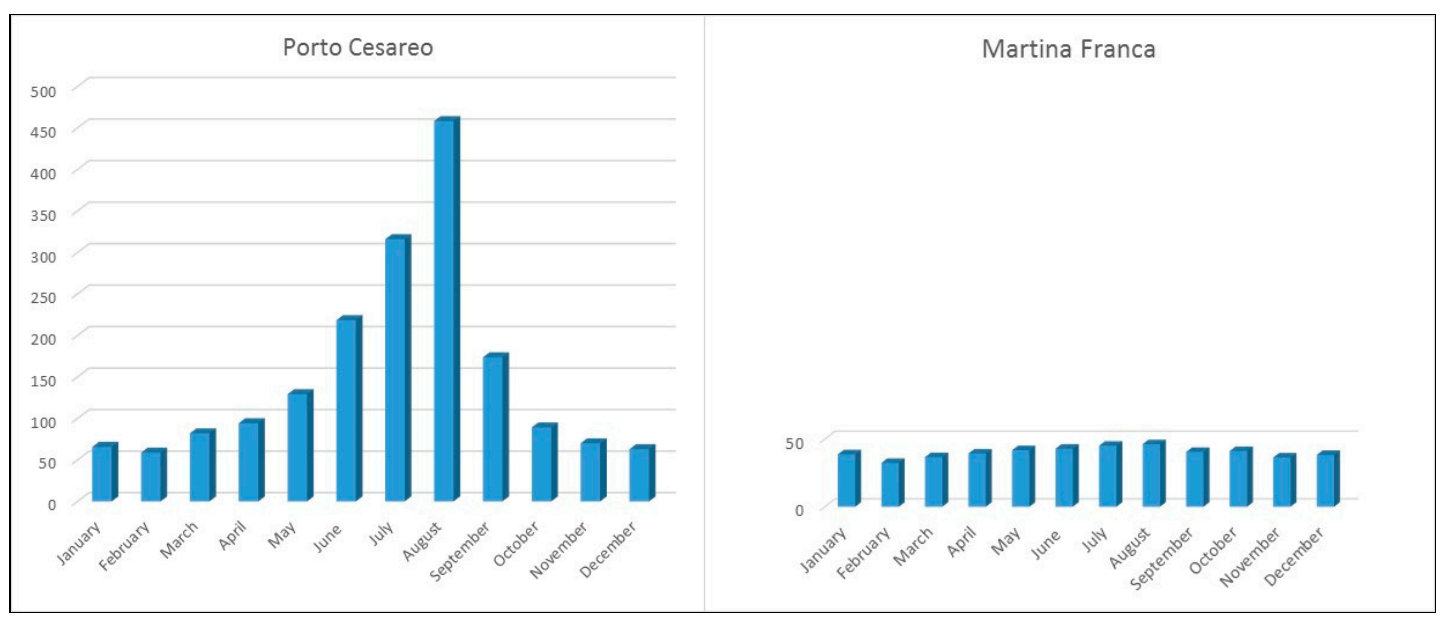

Figure 7. Comparison of monthly waste production between Martina Franca and Po

The second point, that is the existence of high real estate values on the "ring around the city center of Martina Franca can be justified correlated with the high number of seasonal country houses owned by residents the correlation between the variation of density of the urban sprawl and the spatial variation of real estate values.

When we interrogate "Geopoi" system (the official Geographic database of the real estate values of the national Agency of Revenues) we can observe (fig. 8) that the higher value of housing stock is referring to the wider ring around the city, that s the area of maximum density of housing sprawl.

At first glance, the black image in the left corner of figure 8 might seem like a starry sky, tricking the perception of the mind, yet it is a snapshot of what is happening in terms of soil take: it represents the distribution of the built fabric in the countryside of Martina Franca, emphasized by the use of a technique of smoothing. 


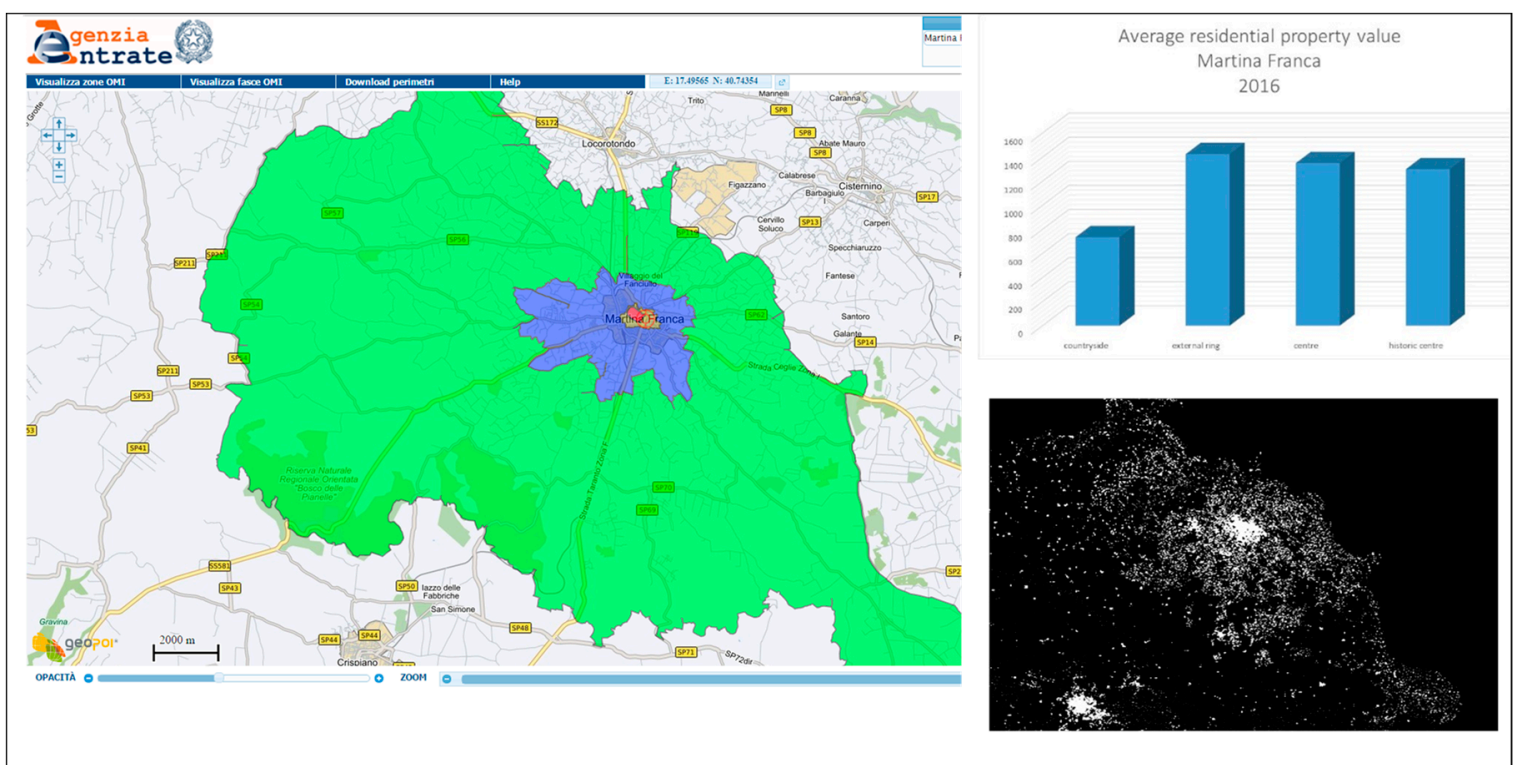

Figure 8. Property market value of Martina Franca in the external neighbours

In fact, the Transition Matrix of Martina Franca (Table 4), in opposition with Porto Cesareo shows a contemporary increase of residential artificial use with the productive use. The property value trends is increasing since 2013 to 2016.

Table 4. The Transition Matrix for Martina Franca as extracted from MITO CS Monitor (Consumption of Soil Monitor)

\section{Categories}

1.1. residential urban areas

1.2. industrial, trade and infrastructure

1.3. mining areas, construction sites, landfills and artifacts and derelict land

1.4. artificial green non-agricultural areas

2.1. arable

2.2. permanent crops

2.3. permanent meadows (grassland)

2.4. heterogeneous agricultural areas

3.1. wooded areas

3.2. areas with shrubs and / or herbaceous

3.3. open areas with sparse or no vegetation

4.1. inland wetlands

4.2. maritime wetlands

5.1. continental waters

5.2. maritime waters

9.9. other uses

Total artificial uses

\begin{tabular}{|r|r|r|r|}
\hline 11 & 12 & 13 & 14 \\
\hline 1938,31 & 0,00 & 0,11 & 0,00 \\
\hline 0,04 & 1029,78 & 0,00 & 0,00 \\
\hline 0,00 & 2,07 & 103,79 & 0,00 \\
\hline 0,00 & 0,00 & 0,00 & 42,05 \\
\hline 10,67 & 10,71 & 4,58 & 0,00 \\
\hline 2,98 & 1,10 & 0,00 & 0,00 \\
\hline 0,00 & 0,00 & 0,00 & 0,00 \\
\hline 0,00 & 0,00 & 0,00 & 0,00 \\
\hline 0,00 & 2,06 & 0,00 & 0,00 \\
\hline 1,04 & 2,58 & 0,00 & 0,00 \\
\hline 0,00 & 0,00 & 0,00 & 0,00 \\
\hline 0,00 & 0,00 & 0,00 & 0,00 \\
\hline 0,00 & 0,00 & 0,00 & 0,00 \\
\hline 0,00 & 0,00 & 0,00 & 0,00 \\
\hline 0,00 & 0,00 & 0,00 & 0,00 \\
\hline 0,00 & 0,00 & 0,00 & 0,00 \\
\hline 1953,05 & 1048,29 & 108,48 & 42,05 \\
\hline & & & \\
\hline
\end{tabular}


Table 5. The estimate of variation of land value due to the transition (Martina Franca)

\begin{tabular}{|c|c|c|c|c|}
\hline Typology of transition & residential & industrial & $\begin{array}{l}\text { mining } \\
\text { landfills } \\
\text { derelict } \\
\text { etc. }\end{array}$ & $\begin{array}{l}\text { non-rural } \\
\text { artificial } \\
\text { green }\end{array}$ \\
\hline From urban to urban artificial soil & 14,62 & 18,39 & 2,62 & 0,00 \\
\hline $\begin{array}{c}\text { From non-artificial to urban } \\
\text { artificial soil }\end{array}$ & 0,84 & 6,00 & 3,45 & 0,80 \\
\hline $\begin{array}{l}\text { land value VuT2 variation from } \\
\text { urban to urban artificial land use } \\
\text { (unit=10 thousands of euros) }\end{array}$ & 134,60 & 233,60 & 69,00 & 0,80 \\
\hline $\begin{array}{c}\text { land value VuT2 variation from } \\
\text { non-artificial to urban artificial land } \\
\text { use (unit=10 thousands of euros) }\end{array}$ & 84,00 & 600,00 & 69,00 & 0,80 \\
\hline
\end{tabular}

\section{Discussion}

When the "transition analysis", by the matrix of land use change has been crossed with a gross estimate of property value variation (translated in terms of multiplier of values, explains in a sufficient way the dynamics that links property values, urban planning and the continuous soil take appears more clear. Until when the change of land use will occur between the acquisition of land and the introduction of property for sale in real estate market, the multiplier effect will represent an invincible reason for entrepreneurs to demand new construction sites.

Scholars in the matter suggest a set of actions: among that, in a special way we consider densification and land plus-value recapture and we tried to read through the analyses of dynamics in Apulian contexts [25].

The first one - densification - looks in our region to be convenient only in case of the built up in free areas (e.g. after demolition, or after change of use like in some case of social housing as shown in point 3.3). It appears - more than the increase of volumes in elevation - an increase of coverage of open spaces inside the built context [26], and sometimes worse, on the external urban fringe.

The second one - land plus-value recapture - can favor the increase of the consumption of soil, in the same way that the increase of pollution could have been caused by the application of the principle that "the polluter should pay" [27]. We remind that the principle that "if industrial producers pollute the environment, then they should pay a bill" can be negatively reversed in the following assumption: "if the producers pay, then they can pollute" in the same way "if constructors pay or compensate", "they can cover the soil by new construction".

We can only consider land value recapture as an element of compensation the environmental damage, when fiscal obligations withdraw funding of urban retraining or improvement (if we reason in the light of weak sustainability).

The examples that have been shown in this paper, anyway, provide the idea that when the soil take is due to the accumulation of actions, in a universe of small urban realities [28], it is very difficult for land value recapture to be effective.

In alternative the principle of strong sustainability (that is pursued with a stronger fiscal regulation and taxation of urban transformation) cannot be easily applied. This approach has been often reminded by american researchers as "fundamental rationale" of containment of land consumption. Land taxation is seen in the form of reduction of income for property managers. It 
should be seen as a way to rehabilitate for instance polluted or abandoned land, tha can be out of the uiltable areas, with the aim of increase ecolocical richness to balance thee urban development.

As we observed the increase of soil consumption, anyway, is very small in the last period. Therefore, action oriented to sustainable development can be more frequently addressed towards a better re-use, especially when not recently built, of existing housing stocks]. The new agenda for urban economics should apply plus value recapture for rehabilitating the built environment and in the same, to enrich the natural stock, reducing soil imperviousness.

Acknowledgments: The Authors acknowledge the strong effort done by the major consultants of MITO Lab: Alessandro Bonifazi Raffaele Attardi and Valentina Sannicandro for collaborating in the research in the field of Soil savings, that have been testified in several analyses done toghether. A further acknowledgement as well is addressed to Gianluca di Cugno, the web master of the Site of Mito Lab, for his continous attention to the website, and to the maintainance of the database of Mito Tips and Giovanni Latrofa and Alessandro Bonifazi for Mitocs.

Author Contributions: As regards the paper, even if the work is due to a common effort, but it is possible to identify a individual contribution: F. Tajani wrote Paragraph 1 and 2, C.M. Torre wrote Paragraphs 3 and 4, and P. Morano wrote paragraph 5.

Conflicts of Interest: The authors declare no conflict of interest.

\section{References}

1. R Meeus S.J. e Gulinck H., Semi-Urban Areas in Landscape Research: A Review. Living Reviews in Landscape Research, 2008 http://www.livingreviews.org/lrlr-2008-3

2. Burkhard B., Kroll F., Müller F. e Windhorst W. (2009), Landscapes Capacities to Provide Ecosystem Services. A Concept for Land-Cover Based Assessments. Landscape Online 2009, 15, 1-22.

3. Wackernagel M; Rees W. Our Ecological Footprint: Reducing Human Impact on the Earth. New Society Publishers, Gabriola BC, 1995

4. Blowers, A. (ed.) Planning for a sustainable environment. Earthscan London, 1993

5. Breheny M. Urban compaction: feasible and acceptable? Cities, 1997, 14(4): 209-217.

6. Daily G.C., Introduction: What are Ecosystem Services?. Nature's Services. Societal Dependence on Natural Ecosystems, Island Press, Washington, 1997.

7. Costanza R., d'Arge R., de Groot R., Farberk S., Grasso M., Hannon B., Limburg K., Naeem S., O'Neill R.V., Paruelo J., Raskin R.G., Suttonkk P., van den Belt M.,. The value of the world's ecosystem services and natural capital. Nature, 1997, 387: 253-260.

8. De Groot R. Environmental Functions as a Unifying Concept for Ecology and Economics. Environmentalist, 1987, 7(2):105-109.

9. Gulinck H. Neo-rurality and multifunctional landscapes. In Brandt J. e Vejre H. (Eds), Multifunctional Landscapes, Vol. 1: Theory, Values and History. WIT Press, Southampton, 63-74, 2004

10. Alterman R. The Challenge of Farmland Preservation: Lessons from a Six-Nation Comparison. Journal of the American Planning Association. 1997, 63(2): 220-243,

11. Dimotta A., Cozzi M., Romano S., Lazzari M.; Loss, Productivity and Cropland Values GIS-Based Analysis and Trends in the Basilicata Region (Southern Italy) from 1980 to 2013. In Gervasi O., Murgante B. Misra S, Rocha A.M., Torre C. M., Taniar D., Apduhan B O., Stankova E., Shangguang W. (eds) Computational Science and Its Applications -- ICCSA 2016 - LCNS. 2016, 9789: 29-45

12. Amato F., Martellozzo F., Nolè G., Murgante B. Preserving cultural heritage by supporting landscape planning with quantitative predictions of soil consumption Journal of Cultural Heritage. 2016: doi: 10.1016/j.culher.2015.12.009.

13. Arcidiacono A.; Ronchi S.; Salata S. Valutazione delle dinamiche evolutive dei servizi ecosistemici nelle aree costiere pugliesi. Reticula 2015, 10: 58-65

14. Munafò M., Assennato F., Congedo L., Luti Tania., Marinosci I., Monti G., Riitano N., Sallustio L., Strollo A., Tombolini I., Marchetti M. Il consumo di suolo in Italia - Edizione 2015. Ispra, Roma, 2015

15. Rose, J., Persson, J.S., Heeager, L.T., Irani, Z.: Managing e-Government: value positions and relationships. Information Systems Journal 2015, 25: 531-571.

16. Bonifazi, A., Sannicandro, V., Attardi, R., Di Cugno, G., Torre, C.M. Countryside vs city: A usercentered approach to open spatial indicators of urban sprawl. In Gervasi O., Murgante B. Misra S, 
Rocha A.M.A.C., Torre C. M. Taniar D., Apduhan B O., Stankova E., Shangguang W. (eds) Computational Science and Its Applications - ICCSA 2016-LCNS, 2016, 9789: 161-176

17. Giuseppe Modica G., Pollino M., Lanucara S., La Porta Luigi., Pellicone Gaetano, Di Fazio S., Fichera C.R. Land Suitability Evaluation for Agro-forestry: Definition of a Web-Based Multi-Criteria Spatial Decision Support System (MC-SDSS): Preliminary Results. In Gervasi O., Murgante B. Misra S, Rocha A.M.A.C., Torre C. M. Taniar D., Apduhan B O., Stankova E Shangguang W (eds) Computational Science and Its Applications - ICCSA 2016 LCNS, 2016, 9788: 399-413

18. Pileri P. Maggi, M. Sustainable planning? First results in land uptakes in rural, natural and protected areas: the Lombardia case study (Italy). Journal of Land Use Science, 2010 5(2): 105 - 122

19. Cerreta M., Inglese P., Malangone V., Panaro S.: Complex value-based Approach for Multidimensional Evaluation of Landscape. In Murgante B., Misra S., Rocha A. M. A. C., Torre C., Rocha J.G., Falcão M.I., Taniar D, Apduhan B.O., Gervasi O. (eds) Computational Science and Its Applications - ICCSA 2014 Part 3 - LCNS 2014, 8581: 382-397

20. Fischel W. A. Zoning Rules! The Economics of Land Use Regulation. Lincoln Institute of Land Policy, Cambridge, MA, 2015

21. Needham B. Land taxation, development charges, and the effects on land-use, Journal of Property Research. 2000, 17(3): 241-257

22. Calavita N. Land Value Recapture in the US: The Case of San Francisco. Advanced Engineering Forum 2014, 11: 330-337

23. Healey P., Purdue M., Ennis F. Gains from Planning? Dealing with the impacts of development. Joseph Rowntree Foundation, York, 1993

24. Alterman R. Land use regulations and property values: The "Windfalls Capture" Idea Revisited. In: Brooks N, Donanghy K. Knapp G.J. (eds) The Oxford Handbook on Urban Economics and Planning. Ch. 33: 755-786 Oxford University Press 2012

25. Morano, P., Tajani F., The Transfer of Development Rights for the Regeneration of Brownfield Sites. Applied Mechanics and Materials. 2013, 409-410: 971-978

26. Attardi R. Pastore E. Torre C.M. "Scrapping” of Quarters and Urban Renewal: A Geostatistic-Based Evaluation. In Murgante B., Misra S., Rocha A. M. A. C., Torre C., Rocha J.G., Falcão M.I., Taniar D, Apduhan B.O., Gervasi O. (eds) Computational Science and Its Applications - ICCSA 2014 - LCNS, 2014, 8581: $430-445$

27. Torre, C.M., Balena, P., Ceppi, C. The devaluation of property due to the perception of health risk in polluted industrial cities. International Journal of Business Intelligence and Data Mining 2014, 9(1): 74-90

28. Nolè G., Murgante B., Calamita G., Lanorte A., Lasaponara R. (2015) Evaluation of Urban Sprawl from space using open source technologies. Ecological Informatics, 2015, 26(2): 151-161

(C) 2016 by the authors; licensee Preprints, Basel, Switzerland. This article is an open access article distributed under the terms and conditions of the Creative Commons by Attribution (CC-BY) license (http://creativecommons.org/licenses/by/4.0/). 